\title{
GRIBAS IZPAUDUMA NOZĪME TIESISKA DARİJUMA NOSLĒGŠANĀ
}

\section{THE MEANING OF EXPRESSION OF INTENT IN LEGAL TRANSACTIONS ${ }^{*}$}

\author{
Laura Kadile, Mg. iur. \\ Latvijas Universitātes Juridiskās fakultātes \\ doktora studiju programmas "Juridiskā zinātne" 2. kursa studente, \\ Latvijas Universitātes Medicīnas fakultātes pētniece
}

\begin{abstract}
Summary
The expression of will is a crucial aspect of lawful transaction in civil law. The will of the individual and its expression is significant in ensuring for the ability of an individual to enjoy and exercise his or her right to self-determination, as well as for the legal transaction to be recognized as valid.

Only the transactions made by a person capable of expressing their free will and being able to be aware of the content and consequences of the legal transaction are in force. Therefore, the observation and assessment of such capacity is particularly important in view of the fact that, in circumstances where a person is unable to express his will freely, he may be denied the right to enter into a legal transaction, or, if the legal transaction has been concluded in circumstances where the individual has not been able to express free will, such transaction may be declared invalid.
\end{abstract}

Atslēgvārdi: tiesisks darījums, gribas izpaudums, brīva griba, privātautonomija.

Keywords: legal transaction, expression of will, free will, private autonomy.

\section{Ievads}

Tiesisks darījums ir nozīmīgākais juridiskais instruments, kuru tiesību subjekti, darbojoties privāto tiesību jomā, izmanto savu mantisko un nemantisko interešu īstenošanai. Tiesiskais darījums tā teorētiskās un praktiskās nozīmes dēḷ ir pats svarīgākais civiltiesību institūts un viens no saistību rašanās pamatiem. Protams, tiesiskā darījuma institūts netiek izmantots abstraktā veidā, jo noslēgti tiek konkrēta veida darījumi, piemēram, pirkuma līgumi, darba līgumi, īres līgumi. Tostarp tiesiski darījumi var tikt noslēgti ārstniecības iestādē, personai atrodoties ierobežotas rīcībspējas stāvoklī vai arī situācijā, kurā tā nespēj saprast savu darbību

This paper is prepared within the research project "Towards a human rights approach for mental health patients with a limited capacity: A legal, ethical and clinical perspective”, No. lzp-2020/1-0397. 
nozīmi vai tās vadīt. Tādēl gribas izteikuma kā tiesiska darījuma nozīmīgākā pamatelementa konstatēšana ir svarīga, vērtējot tiesiska darījuma spēkā esamību.

\section{Tiesiska darījuma jēdziens un tā izpratne}

Civiltiesības regulē līdztiesīgu dalībnieku savstarpējās mantiskās un nemantiskās tiesiskās attiecības, kā arī dažādu labumu piederību un apgrozību. Civiltiesību pamatprincips ir privātautonomija, kas savukārt ir personiskās brīvības izpausme. ${ }^{1}$ Tiesisks darījums ir svarīgākais no juridiskajiem faktiem. ${ }^{2}$ Tieši tiesiskajos darijumos visplašāk izpaužas privātpersonu autonomijas princips. ${ }^{3}$ Tādēl tieši tiesiskais darījums visupirms ir privātautonomijas līdzeklis. ${ }^{4}$ Tiesiska darījuma institūts ir ietverts Latvijas Civillikuma ceturtās daḷas "Saistību tiesības" pirmajā nodaḷā “Tiesiski darījumi vispār”. Attiecīgi Civillikuma 1403. pants ietver tiesiska darījuma definīciju (tiesisks darījums ir atḷautā kārtā izdarîta darbība tiesisku attiecību nodibināšanai, pārgrozīšanai vai izbeigšanai). ${ }^{5}$

Interpretējot iepriekš minētajā tiesību normā ietverto tiesiska darījuma jēdzienu gramatiski, pirmkārt, ir izceḷams, ka darījums likuma izpratnē var būt tikai "tiesisks". Tas gan izriet arī no paša jēdziena nosaukuma, jo Civillikumā tiek lietots jēdziens "tiesisks darījums", tādā veidā jau uzreiz pašos pamatos izslēdzot iespēju prettiesisku darījumu uzskatīt par tādu, kas varētu nodibināt, pārgrozìt vai izbeigt jebkādas tiesiskas attiecības. Tāpēc tiesisks darījums ir vai nu likumā paredzēta rīcība, vai arī rīcība, kura tieši nav likumā paredzēta, bet kura nav pretrunā ar likumu. ${ }^{6}$

Tomēr ne katra tiesību subjektu veikta darbība būtu a priori atzīstama par tiesisku. Civillikuma 1403. pants būtu jātulko sistēmiski ar Civillikuma 1404. pantư ${ }^{7}$, kurā uzskaitīti pieci darījumam nepieciešamie elementi, kas ņemami vērā, vērtējot darījuma juridisko spēku. Attiecīgi - darījuma dalībnieki, tiesisku darījumu priekšmets, gribas izteikums un īstums, darījuma sastāvdal̦as, kā arī forma. Aplūkojot tiesiska darījuma regulējumu sistēmiski ar citu valstu tiesībās regulēto tiesību institūtu, tad, piemēram, Francijas Civilkodekss ${ }^{8}$ tieši nenošķir tiesisku darījuma institūtu no līguma institūta. Sistēmiski šis institūts iekḷauts Francijas Civilkodeksa trešajā daḷā "Īpašuma iegūšanas veidi”, kurā regulēti tādi īpašuma iegūšanas veidi kā mantošana, dāvinājums un testaments, līgumi un citas saistības. Trešā sadaḷa (Titre troisième) savukārt reglamentē divpusēja tiesiska darījuma - līguma - institūtu. Šeit būtiski izcelt, ka termins "tiesisks darījums” Latvijas tiesību sistēmā ir atzīstams par plašāku jēdzienu nekā "līgums". Lìgums ir atzīstams par darījumu, bet ne jebkurš darījums ir uzskatāms par līgumu.

${ }^{1}$ Balodis K. Ievads civiltiesībās. Rīga: Zvaigzne ABC, 2007, 20. lpp.

2 Гамбаров Ю. С. Курс гражданского права. Том I. Часть общая. С.-Петербург: типография М. М. Стасюлевича, 1911, с. 668.

${ }^{3}$ Balodis K. 2007, 150. lpp.

${ }^{4}$ Wolf M., Neuner J. Allgemeiner Teil des Burgerlichen Rechts, 10. Auflage. Munchen: Beck, 2012, \$ 28, Rn. 1, S. 311; Medicus D. Allgemeiner Teil des BGB, 10. Auflage, Heidelberg: Muller, 2010, Rn. 175, S. 79.

${ }^{5}$ Civillikums: LV likums. Ziṇotājs, 30.01.1992., Nr. 4.

${ }^{6}$ Grūtups A., Kalniņš E. Civillikuma komentāri. Trešā daḷa. Lietu tiesības. Īpašums. 2. papild. izd. Rīga: Tiesu nama aǵentūra, 2002, 115. lpp.

7 Civillikums: LV likums. Ziņotājs, 30.01.1992., Nr. 4.

${ }^{8}$ Grazhdanskij kodeks Francii (Kodeks Napoleona). Code civil des Francais (Code Napoleon). Perevod s francuzkogo. Moskva. Berlin. Infotropik Media, 2012, S. 194. 
Savukārt Vācijas tiesību regulējumā, proti, Vācijas Civillikumā (Bürgerliches Gesetzbuch $^{9}$ (turpmāk - BGB), atšķirībā no Francijas Civilkodeksa un Latvijas Civillikuma regulējuma, piemēram, netiek izdalīi un izsmel̦oši vienkopus uzskaitīti tiesiskā darījuma elementi, kā arī definēts pats tiesiska darījuma jēdziens salīdzinājumā ar Latvijas Civillikuma regulējumu. Neraugoties uz to, arī Vācijas tiesībās, tāpat kā Latvijas un Francijas tiesībās, par vispārēju un imperatīvu darījuma elementu tiek atzīts vismaz viens dalībnieka gribas izteikums. ${ }^{10}$ Tomēr, tāpat kā visās citās valstīs, kuru civiltiesības pamatā ir recipētas no romiešu tiesībām, arī BGB ietver tiesību normas, kurās noteikti gadījumi, kad darījums ir atzīstams par spēkā neesošu. Minētie gadījumi ir plašāki par Latvijas normatīvajā regulējumā ietvertajiem pamatiem.

Vienotas Eiropas līgumtiesību izpratnes un satura veidošanai, tiesiska darījuma jēdziena detalizētākai izpratnei nepieciešams aplūkot arī Vienotā norādījumu projekta regulējumu ${ }^{11}$ (Draft Common frame of Reference; turpmāk - DCFR). DCFR norādītā klasifikācija, juridiskus aktus nodalot no līgumiem, neatbilst Latvijā pieņemtajai tiesisku darỉjumu klasifikācijai. Saskaņā ar DCFR, proti, tā II grāmatas 1:101. pantu, par juridisku aktu tiek atzìts jebkurš izklāstījums vai piekrišana, kas tieši vai netieši izteikta no rīcības, kurai kā tādai ir juridisks spēks. Tas var būt vienpusējs, divpusējs vai daudzpusējs. Savukārt ar līgumu tiek saprasts juridisks pamats, kurš sastāv vismaz no viena vai vairākiem gribas izteikumiem, kas patstāvīgi vai saistībā ar citiem spēkā esamības priekšnoteikumiem nodrošina tiesisko attiecību izveidi vai rada citas tiesiskās sekas. ${ }^{12}$ Tādēl tieši griba ir darījuma noslēgšanas pamats, kas savukārt veidojas dažādu motīvu ietekmē. Tieši personas gribas izteikums nosaka vēlamo tiesisko seku iestāšanos. Tiesiskās sekas pašos tās pamatos sastāv no tiesību vai tiesiskajām attiecībām. ${ }^{13} \mathrm{Lìdz}$ ar to darỉjums pēc savas būtības būtu atzīstams par gribas aktu, kurā izškị darījuma dalībnieku iekšējo gribu un šīs gribas izpausmi.

\section{Gribas izteikums kā tiesiska darijuma pamatelements}

Līdz pat šodienai dažādu zinātņu pārstāvji ir centušies definēt brīvas gribas jēdzienu, tostarp filozofijas zinātnes dižgari. Filozofs Džons Loks gribu raksturojis kā dvēseles spēku izdarìt domāšanas operācijas un ķermeņa kustības, izceḷot, ka griba ir zināmu nodomu, mērḳu un uzdevumu piepildīšana ar mūsu apziṇas aktīvo spēku palīdzību. Griba ir mūsu apziṇas darbīgā puse. Bez gribas apziṇai vēl ir daudz citu funkciju - domāšana, jūtas, atmiņa, bet nav šaubu, ka šo citu funkciju darbība iespējama vienīgi tad, ja gribu uzlūkojam kā darbošanās priekšnoteikumu. ${ }^{14}$ Tādējādi Džona Loka filozofija vērš sava klausītāja uzmanību uz gribu kā

\footnotetext{
${ }^{9}$ Bürgerliches Gesetzbuch - German Civil Code (Vācijas Civillikums). Pieejams: http://www.gesetze-iminternet.de/englisch_bgb/ [aplūkots 01.03.2021.].

${ }^{10}$ Larenz K., Wolf M. Allgemeiner Teil des bürgerlichen Rechts, 8. Aufl. München: Beck, 1997, S. 123.

11 Communication from the Commission to the European Parliament and the Council. A more coherent European contract law. An Action Plan. COM (2003) 68 final. Commission of the European Communities. Brussels, 12.02.2003.

12 Beale H., Fauvarque-Cosson B., Rutgers J., Tallon D., Vogenauer S. Cases, Materials and Text on Contract Law. $2^{\text {nd }}$ ed. Oxford: Hart Publishing, 2010, p. 42.

13 Creifelds C. Rechtswörterbuch, 21. Auflage. München: Verlag C. H. Beck, 2014, S. 1028.

14 Students J. A. Gribas audzināšanas metodes. Izglītības Ministrijas Mēnešraksts, 1929, Nr. 2, 112. lpp.
} 
priekšnosacījumu it visam, tostarp skaidri nodalot gribas un apziṇas nozīmi šādos ķermeņa funkciju procesos.

Par gribu 4. gadsimtā bija izteicies arī Svētais Augustīns. Viṇš izteica pieñēmumu, ka dvēseles un k̦ermeņa darbības kontrolē griba. Griba ir tā, kas virza dvēseli pašizziṇai, griba no dvēseles “izṇem” idejas, kas tajā ir. Augustīns nesniedz noteiktu gribas jēdziena definīciju, no viņa darbiem ir pilnīgi skaidrs, ka griba (voluntas - latīnu val.) ir tas, ar ko mēs izvēlamies kaut ko darìt. Citiem vārdiem, tā ir patstāvīga un pilnīgi brīva saprātīgas dvēseles spēja pieṇemt lēmumu, izvēloties kādu no rīcības iespējām. Šìs rīcības iespējas piedāvā pārējās dvēseles spējas - sajūtas, dziñas vai prāts (intellectus, ratio). ${ }^{15}$

Neskatoties uz atsevišksu filozofu centieniem definēt gribas jēdzienu un tā saturu, filozofijas zinātnē "brīvas gribas" definīcija līdz pat šai dienai nav skaidrota, tāpēc pakḷauta plašām diskusijām. ${ }^{16}$

Gribas izteikuma funkcija Civillikumā ir cieši saistīta ar privātautonomijas principu. Privātautonomija ir indivīda tiesisko attiecību pašnoteikšanās princips pēc viņa gribas. ${ }^{17}$ Tiesiskās attiecỉbas, noslēdzot tiesiskos darījumus, indivīds var veidot pēc savas gribas. Tiesiskais darijums ir privātautonomijas lìdzeklis, ${ }^{18}$ bet gribas izteikums savukārt ir līdzeklis tiesiska darījuma izpildei. Līdz ar gribas izteikumu tiek noteikts, kādas tiesiskās sekas tiesiskais darījums var radīt. Gribas izteikuma nozīme ir spēja tiesiski ar to rīkoties. Kā norādījis Vācijas tiesību zinātnieks D. Medikus, "Gribas izteikums ir tiesiska darījuma līdzeklis, kas savukārt ir arī privātautonomijas līdzeklis". ${ }^{19}$

N̦emot vērā, ka tiesiski darījumi ir iedalāmi vienpusējos un divpusējos (daudzpusējos) darījumos, gribas izteikums un tā īstums ir ņemams vērā, noslēdzot, piemēram, līgumu, kurš ir viens no tiesiska darījuma veidiem un kura noslēgšanai ir nepieciešama pušu vienošanās, kā arī vērtējams vienpusējā tiesiskā darījumā. Tā, piemēram, līgumu kā vienu no tiesiska darījuma veidiem atbilstoši Civillikuma 1427. panta nosacījumiem veido divi saskanīgi gribas izteikumi.

N̦emot vērā, ka tiesisks darījums ir tiesību subjektu gribas akts, par katra tiesiska darījuma pamatelementu Civillikuma 1427. panta izpratnē atzīstams gribas izteikums, t. i., uz noteiktu tiesisku seku iestāšanos vērsts privāts gribas izpaudums. ${ }^{20}$ Gribas izteikums ir personas gribas izpaudums, kas vērsts uz noteiktu tiesisko seku iestāšanos. ${ }^{21}$ Gribas izteikums atbilstoši Civillikuma 1427. pantam ${ }^{22}$ pieder pie tiesiska darījuma būtības, bet divpusējā vai vairākpusējā darījumā vajadzīgs visu tā dalībnieku saskanīgs gribas izteikums. Kamēr griba nav vēl izteikta, tai nav nekāda tiesiska spēka. Turklāt tieši personas brīvi pausta griba ir ārējs apliecinājums tam, ka darïjuma dalïbnieks vēlas panākt darījumam raksturīgo

\footnotetext{
15 Stump E., Kretzman N. (eds.). The Cambridge Companion to Augustine. Cambridge: Cambridge University Press, p. 222.

${ }^{16}$ Habermeyer, E. Saß, H. Ein am Willensbegriff ausgerichteter, symptomorientierter Ansatz zur Prufung der Geschaftsfahigkeit. Fortschritte der Neurologie und Psychiatrie, 2002, Vol. 70 (1), S. 5-10.

17 Flume W. Allgemeiner Teil des Bürgerlichen Rechts, Bd. 2 - Das Rechtsgeschäft, 4. Auflage. Berlin: Springer, 1992, \$1, S. 1 .

18 Wolf M., Neuner J. Allgemeiner Teil des Burgerlichen Rechts, 10. Auflage. Munchen: Beck, 2012, \$28, Rn. 1, S. 311; Medicus D. Allgemeiner Teil des BGB, 10. Auflage, Heidelberg: Muller, 2010, Rn. 175, S. 79.

${ }_{19}$ Medicus D. Allgemeiner Teil des BGB, 10. Auflage, Heidelberg: Muller, 2010, Rn. 175, S. 79.

20 Augstākās tiesas Senāta Civillietu departamenta 15.12.2010. spriedums lietā Nr. SKC-157/2010.

${ }^{21}$ Kalniņš E. Tiesisks darījums. Privāttiesību teorija un prakse. Rīga: Tiesu nama aǵentūra, 2005, 137. lpp.

22 Ibid.
} 
tiesisko seku iestāšanos. ${ }^{23} \mathrm{Līdz}$ ar to divpusēja vai daudzpusēja tiesiska darījuma noslēgšanas gaitā, atšķirībā no vienpusēja tiesiska darījuma, ir jākonstatē tieši brīvas gribas rezultātā sniegtā oferte un akcepts.

Gribas saskaņošana nav atzīstama par vispārēju prasību, kas būtu attiecināma uz ikviena tiesiska darījuma noslēgšanu. Saskanīgs gribas izpaudums ir nepieciešams, tikai noslēdzot daudzpusējus darījumus. Tātad minētā prasība nav attiecināma uz vienpusējiem darījumiem, jo tie sastāv no vienas personas gribas izteikuma.

Lìdz ar to gribai, lai rastos tiesiskas sekas, ir jābūt izteiktai, izrādìtai, izpaustai kādā objektīivi uztveramā veidā (sk. Civillikuma 1428. pantu), izsakot savu piekrišanu konkrētā darījuma noslēgšanai. Piekrišana ir kāda fakta vai priekšlikuma pozitīva vērtējuma izpausme, kas var būt gan darījuma veidošanas sastāvdaḷa (akcepts), gan kāda stāvokḷa, fakta, arī pārkāpuma apliecinājums. ${ }^{24} \mathrm{Nav}$ šaubu, ka pušu patiesā griba, kas nav atradusi izpausmi gribas izteikumā, jāṇem vērā jautājumā par darījuma spēku, tomēr ne visos gadijumos, bet tikai likumā norādītajos gadijumos. Citādi var tikt sagrauta katra darījuma un tiesību stabilitāte kopumā. Nevar, piemēram, atcelt gribas izteikumu, pamatojoties uz to, ka tas izdarìts aiz izklaidības un tāpēc neatbilst patiesai gribai. Nevar atsaukties, lai apgāztu darījumu, uz gribas iekšējiem motīviem, ciktāl tie nav izpaudušies gribas izteikumā, un tāpēc arī tie nepakḷaujas otras puses apsvērumiem. ${ }^{25}$

Kopumā izšķir trīs galvenās brīvas gribas sastāvdaḷas jeb komponentes no filozofijas viedokḷ. ${ }^{26}$ Pirmais elements ir tiesības brīi rīkoties, ar to saprotot brīvu iespēju izvēlēties starp vairākām alternatīvām. ${ }^{27}$ Ja cilvēkam nav dota iespēja izvēlēties no vairākām alternatīvām un tam ir noteikts rīkoties kādā ìpašā un jau iepriekš noteiktā veidā, nevar atzìt, ka tam piemīt tiesības brīvi rīkoties. Otrkārt, brīva rīcība var tikt saprasta kā mērḳtiecīga rīcība vai izvēle. Uzvedība nav uzskatāma par brīvas gribas vadītu, ja persona nerīkojas skaidri saprotama mērḳa labā. Treškārt, lai persona spētu rīkoties brīvi, šīs rīcības pamatā ir jābūt leǵitīmam iemeslam, ${ }^{28}$ kas pamato personas izvēli, izšḳiroties par labu vienai no vairākām alternatīvām.

Visi iepriekš ieskicētie mēǵinājumi izveidot vispārpieņemtu brīvas gribas definīciju tomēr nespēj atrisināt pamatproblēmu, proti, brīvas gribas konstatēšanu, jo tieši bez brīvi pausta gribas izteikuma tiesiskais darījums nevar pastāvēt.

\section{Gribas izpauduma konstatēšana tiesiskā darījumā}

Kā norādījis Virdžīnijas Universitātes (ASV) profesors R. E. Skots, "precīza gribas izteikumu saskaņošanas konstatēšana ir pamats, lai noteiktu, vai konkrēto

${ }^{23}$ Larenz K., Wolf M. Allgemeiner Teil des Bürgerlichen Rechts, 9. Auflage. Munchen: C. H. Beck, 2004, §22, S. 1.

${ }^{24}$ Latvijas Republikas Civillikuma komentāri. Ceturtā daḷa. Saistību tiesības. Autoru kolektīvs prof. K. Torgāna vispārīgā zinātniskā redakcijā. Rīga: Mans İpašums, 1998, 37., 40. lpp.

25 Agarkovs M. M., Bratuss S. N., Genkins D. M., Serebrovskis V. I., Škundins Z. I. Civīltiesības. I sējums. Prof. M. M. Agarkova un prof. D. M. Genkina redakcijā. Rīga: Latvijas Valsts izdevniecība, 1946, 119.-120. lpp.

${ }^{26}$ Walter H. Neurophilosophy of free will: From libertarian illusions to a concept of natural autonomy. Cambridge: MIT Press, 2001.

${ }^{27}$ Kane R. The significance of free will. New York: Oxford University Press, 1998.

${ }^{28}$ Free will and mental disorder: Exploring the relationship. Pieejams: https://www.ncbi.nlm.nih.gov/pmc/ articles/PMC2975916/\#CR2 [aplūkots 01.03.2021.]. 
savstarpējo apsolījumu izpildi var aizsargāt ar civiltiesiskiem aizsardzības līdzekliem"29. Gribas īstuma noskaidrošana ietver vairākus kritērijus. Pirmkārt, jāpārliecinās, vai persona vispār var paust savu viedokli mutiski, rakstiski vai ar kādām citām darbībām, kas nepārprotami liecina par personas konkrētu gribu. Šādu iespēju paredz Civillikuma 1428. panta pirmā un otrā daḷa, kurā norādīts, ka gribu var izteikt vai nu noteikti, vai klusējot. Turklāt noteikts gribas izteikums var būt veikts vai nu ar vārdiem (mutiski vai rakstiski), vai ar zīmēm, kam ir vārdu nozīme. Otrkārt, jānoskaidro, vai persona saprot, ko tieši viṇa vēlas ierakstìt tiesiska darījuma tekstā, proti, kādas būs līdzēja tiesības un pienākumi. Un, treškārt, vai persona apzinās savas rīcības sekas, proti, kādas tiesības un rīcības brīvības apjoms tiks piešķirts līdzējam. ${ }^{30}$

Lai noskaidrotu patieso tiesiska darījuma dalïbnieku gribu, noslēdzot tiesisko darījumu, tiesai, kā tas atzīts Vācijas tiesas praksē, ir jāpārbauda, vai darījuma dalībnieks "pieṇēmis neatkarīgu lēmumu, balstoties uz racionāliem apsvērumiem un izšksiroties par labu tam, ko uzskatījis par pareizu tā brīža izvēli, vai darïjuma dalībnieka tā brīža pārmērīgos apsvērumus tiesiska darījuma noslēgšanas brīdī, kas radušies garīgu traucējumu iespaidā, un personas gribu kontrolēja tādā apmērā, kas izslēdz darījuma dalībnieka brīvu gribu"31.

Lai noteiktu, vai persona, noslēdzot tiesisku darījumu, ir spējusi paust brīvu gribas izpaudumu, ir jāspēj atbildēt uz juridisku jautājumu, kā izšķirošo faktoru vērtējot konkrētās personas vispārīgo ainu, ņemot vērā personas iepriekšèjo medicīnas vēsturi un citus ārējos apstākḷus. ${ }^{32}$ Tādēḷ pirmšḳietami noteikt, ka šāds gribas izteikums būtu nosakāms tikai pēc biologiskiem un neirologiskiem atklājumiem, nebūtu pareizi, n̦emot vērā, ka esošās juridisko un medicīnas, precīzāk, psihiatrijas, zināšanu atšķirības īpaši apgrūtina juridiskajā strīdā iesaistītos psihiatrijas ekspertus - izprast juridiskos priekšnoteikumus un piemērot tos praktiski. Eksperti ir atzinuši, ka saskaras ar izaicinošu uzdevumu, saskaņojot tiesību teoriju ar psihiatriski medicīnisko teoriju, lai tās varētu kalpot kā noderīgs lēmuma pieṇemšanas palīgs tiesību piemērotājam. ${ }^{33}$

Šobrīd spēkā esošā tiesību doktrīna un tiesu prakse Vācijā arvien vairāk uzsver, ka ne vien personas griba, bet arī intelekts ir ņemams vērā gribas izteikuma noteikšanā. Ir atzīstams, ka nepietiek vien ar gribas trūkumiem, lai atzìtu, ka persona nav bijusi spējīga paust brīvu gribas izpaudumu, jo arī intelektuāli augsti attīstīts cilvēks var būt nespējīgs paust spēkā esošu un brīvu gribas izpaudumu apstākḷos, ja persona nespēj pieṇemt saprātīgus lēmumus. ${ }^{34}$

${ }^{29}$ Scott R. E., Leslie D. L. Contract Law and Theory. The Michie Company. Law Publishers. Charlottesville, Virginia, 1995, p. 155.

${ }^{30}$ Mazapša A. Rīcỉbspējas institūta tiesiskais regulējums un tā piemērošana praksē. Jurista Vārds, 17.05.2016., Nr. 20 (923), 16.-25. lpp.

${ }^{31}$ Vācijas Impērijas tiesas (Reichsgeriht) 06.10.1930. spriedums lietā Nr. IV 583/29. Pieejams: https://dejure. org/dienste/vernetzung/rechtsprechung?Gericht=RG\&Datum=06.10.1930\&Aktenzeichen=IV\%20583/29

32 Cording C. Kriterien zur Feststellung der Testier(un)fahigkeit. Zeitschrift fur Erbrecht und Vermogensnachfolge (ZEV). München: C. H. Beck, 2010, S. 115 (117).

${ }^{33}$ Oefele K. v, Saß, H. Die forensisch-psychiatrische Beurteilung von freier Willensbestimmung und Geschäftsfähigkeit. Versicherungsmed, 1994, S. 167 (169). Autori konfliktu raksturo vēl spēcīgāk, nosakot, ka "No psihiatrijas perspektīvas brīva gribas izpauduma teorētiskā konstrukcija, attiecīgi šādas gribas noteikšana nav iekḷaujama nosologijas sistēmä”; Janzarik W. Seelische Struktur als Ordnungsprinzip in der forensischen Anwendung. Der Nervenarzt. Berlin: Springer Medizin Verlag GmbH, 1993, S. 427 (432).

${ }^{34}$ Staudinger J. von. Kommentar zum Bürgerlichen Gesetzbuch mit Einführungsgesetz und Nebengesetzen. Buch 1, Allgemeiner Teil, $\$ \$ 90-124,130-133$. Neubearbeitung. Berlin: Sellier / de Gruyter, 2017, $\$$ 
Vācijas tiesībās šobrīd jau pastāv vienots viedoklis, ka atbilstoši sertificētiem tiesu ekspertiem būtu jāsadarbojas ar tiesu lietas iztiesāšanas gaitā un sprieduma sastādīšanas procesā ${ }^{35}$, sniedzot tiesai nepieciešamās konsultācijas par konkrētiem medicīniskiem terminiem, kā arī izskaidrojot medicīniskajā dokumentācijā un eksperta atzinumos ietverto terminologiju un secinājumus.

\section{Kopsavilkums}

1. Tiesisks darījums pēc savas būtības ir tā dalïbnieku saskanīgi gribas izteikumi daudzpusējā tiesiskā darījumā un dalïbnieka gribas izteikums vienpusējā tiesiskā darījumā. Tādēl tieši brīvi pausts gribas izpaudums, kas vērsts uz noteiktu tiesisko seku iestāšanos, ir atzīstams par privātautonomijas līdzekli, tiesiska darījuma pamatelementu un darījuma spēkā esamības priekšnoteikumu. Vienpusējā tiesiskā darījumā ir ņemams vērā un vērtējams viens gribas izteikumus, kas šo darījumu veido.

2. Noslēdzot tiesisko darījumu, no personas tiek sagaidīta izpratne par darïjuma tiesisko dabu, tajā ietvertajiem noteikumiem un tā tiesiskajām sekām. Tieši tiesas uzdevumos ietilpst darījumu iztulkot, noskaidrot darījuma dalïbnieku patieso gribu.

3. Lai varētu konstatēt personas brīvas gribas izpaudumu un personas apziṇas spējas noslēgt tiesisku darījumu, attiecīgi to, vai persona apzinās šāda darījuma sarežgitîibu, tā uzbūvi, tajā ietverto terminoloǵiju un darījuma tiesiskās sekas, jāspēj novērtēt, vai persona savu gribu spēj izpaust, vai iepriekš pausto gribu ir sapratusi un apzinās savas rīcības sekas, tostarp ievērojot personas medicīnisko vēsturi un citus ārējos apstākḷus.

4. Lai novērtētu un izlemtu to, vai persona tiesiska darījuma noslēgšanas brīdì ir paudusi brīvu gribu, kā arī to, vai persona ir apzinājusies tiesiska darījuma saturu un sapratusi no tiesiskā darījuma izrietošās tiesiskās un faktiskās sekas, nepieciešams nodrošināt tiesību zinātnieku un medicīnas speciālistu kopīgu sadarbību, konstatējot un vērtējot brīvas gribas izpaudumu tiesiskā darījumā.

104-115, Rn. 20. Šāda atziṇa pausta arī LKG Frankfurt, Urteil vom 28.11.1991. - 15 U 13/89, NJW-RR 1991, S. 763 (764).

${ }^{35}$ Jessnitzer K., Frieling G. Der gerichtliche Sachverständige. Ein Handbuch fur die Praxis. Koln: Carl Heymanns Verlag, 2000, S. 51. 